\title{
Paralysis over Palestine: QUESTIONS OF STRATEGY
}

\author{
JEFF HALPER
}

This essay by a prominent Israeli activist grows out of concern that advocacy efforts in support of the Palestinian cause bave remained stuck at the protest-informational stage of combating disparate manifestations of the occupation. What is needed, the autbor argues, is a strategy to mobilize the vast range of civil society groups-Palestinian, Israeli, and international-to forge an effective lobbying and advocacy force that can lend the Palestinian leadership public support and a measure of parity with Israel. Intended as a starting point for debate, the essay explores the possibilities of a "middle range" strategy that would articulate the essential "red line" elements crucial to any just and sustainable settlement, provide a coordinated strategy of advocacy, and explore a range of "endgames," including a regional approach to resolving the conflict if the "two-state solution" is found to be impossible because of irreversible "facts on the ground."

The ClAim thAT we in Palestine/Israel find ourselves in a historical moment, at a "fateful crossroads," sounds like a worn cliché. How many historical moments have we entered and passed through, seemingly without fateful consequences, in the past decades? The illusion that nothing is final, that the occasional "crises" in the Middle East can be weathered without lasting effect, arises from following events on a purely political level: conflicts, negotiations, peace plans, initiatives, policies of one leader or another.

A wider view that includes the "facts on the ground" presents a far different picture. The radical physical transformation of Palestine/Israel that took place in 1948 has been extended and deepened in Israel's concerted campaign to impose a permanent "matrix of control" over the occupied territories. In this, I would argue, it has succeeded. Since the occupation began, the demolition of 12,000 Palestinian homes since 1967; the "quiet transfer" of more than half a million Palestinians from the West Bank, "East" Jerusalem, and Gaza since the occupation began; the relentless process of "Judaization" that has transferred more than 70 percent of West Bank land from Palestinian into Israeli hands; the construction of a vast web of settlement blocs and Israeli-only

JefF HALPER, an anthropologist, is the coordinator of the Israeli Committee Against House Demolitions (ICAHD; www.icahd.org), part of Israel's critical peace movement (sometimes referred to as "left of Peace Now"). Working closely with a wide range of Palestinian organizations, faith-based and human rights groups, and international NGOs, ICAHD is actively engaged in virtually all levels of conflict resolution, including advocacy, lobbying, protest, resistance, information-passing, and active campaigning.

\footnotetext{
Journal of Palestine Studies Vol. XXXIV, No. 2 (Winter 2005), pp. 55-69 ISSN: 0377-919X; electronic ISSN: 1533-8614. (c) 2005 by the Institute for Palestine Studies. All rights reserved. Please direct all requests for permission to photocopy or reproduce article content through the University of California Press's

Rights and Permissions website, at http://www.ucpress.edu/journals/rights.htm.
} 
"bypass roads"; the literal imprisonment of millions of Palestinians behind a "separation barrier"; the impossibility of Palestinian free movement among their enclaves by external and internal "closures"; the pursuit of policies fostering impoverishment, infrastructural destruction, and dedevelopment; the institution of military orders and discriminatory laws affecting every detail of Palestinian life as well as Kafkaesque planning and administrative procedures; undermining the fabric of Palestinian society by coercing thousands of Palestinians into collaboration; employing state terror on a massive scale to break the will of the people-all these constitute accumulative "moments" more uncompromising by far than any mere political development could be.

\section{A New Opportunity for Peace?}

The passing of Arafat has been heralded as the beginning of a new era offering promising opportunities to resolve what British prime minister Tony Blair called "the single most pressing political challenge in our world today." Hardly was Arafat in his grave than Blair and President Bush solemnly declared their commitment to revitalizing the moribund road map. Given the diplomatic paralysis of the past four years and the despair it has sown among all those working for a just peace in the region, the fact that many see this as heartening news is understandable.

From a perspective grounded in the physical transformation of Palestine/ Israel, however, the situation looks less encouraging. Israel's aggressive policy of creating "facts on the ground" shows no sign of abating. Settlement construction continues apace. The population of Ma'ale Adumim, a settlement-city controlling both "Greater" Jerusalem and north-south Palestinian movement in the West Bank, is expected to grow from its present 30,000 to more than 70,000 in the next five years. Israel is planning an entirely new city, Givat Yael, on the lands of Wallajeh between Jerusalem and Bethlehem, which is to have a population of 55,000 in its first stage. Three ultra-orthodox settlementsBeitar Ilit to the west of Bethlehem, Tal Zion near Ramallah, and Mod'in Ilit to the west of Ramallah-are the fastest growing in the West Bank. The construction of the wall, accompanied by massive land expropriations and population transfer, also continues. The most recent indication of Israel's intention to retain permanent control of the West Bank is the plan unveiled in September 2004 for an eighty million dollar network of Palestinian highways, including sixteen "passages," bridges and tunnels that give the Palestinians "transportational" but not territorial contiguity while preserving Israel's own exclusive network of settler highways. If Sharon is able to present himself as a statesman genuinely interested in achieving peace with the Palestinians, it is because he has completed his program of reconfiguring the country to an extent that a genuine two-state solution has been rendered impossible. Even if Israel were to relinquish the vast majority of its settlements and up to 85-90 percent of the occupied territories, its control would not be endangered in the slightest.

To be sure, Israel's matrix of control could be dismantled if the international community had the required political will, since "occupation" is defined in 
international law as a temporary military situation that can only be resolved through negotiations. Sharon had little to fear concerning political will; for extra insurance he worked hard to transform Israel's presence in the West Bank and East Jerusalem from an occupation into a permanent political fact recognized and accepted by the only party that matters, the United States. That was accomplished in June 2004, when the American Congress endorsed, almost unanimously, the Bush-Sharon agreement of April whereby Israel would not be required under any future peace process to withdraw to the 1967 lines or to abandon its major settlement blocs (which the congressional resolution calls "major Israeli population centers in Israel"). This blatant laundering of the settlements' patent illegality represented a radical shift in American foreign policy, effectively nullifying the basis agreed to by all parties for resolving the conflict, namely UN Security Council resolutions 242 and 338, which call on Israel to withdraw from the territories seized in June 1967 in return for security guarantees from its Arab neighbors. The agreement, now part and parcel of U.S. policy, also fundamentally contradicts the road map, which calls for an end to occupation and the establishment of a viable Palestinian state through negotiations. By removing the settlement blocs from negotiations, Congress and the Bush administration in effect reduced the territory left for the Palestinians to negotiate to only 70-80 percent of the West Bank-a truncated 10-15 percent of the original Palestine. And since then, American empire, in which Israel plays a key role, has been confirmed by Bush's reelection.

This is bad news for advocates of a just and sustainable peace. The good news is that concern over the Israeli-Palestinian conflict's destabilizing effects on Europe and the "moderate" Arab states, including its linkage to global terrorism and radical Islam, has lent it an unprecedented urgency as the conflict endangering world peace. At the same time, blame for prolonging the conflict is increasingly shifting from the Palestinians to Israel: some 59 percent of Europeans polled by the European Commission in October 2003 named Israel as the greatest threat to world peace. ${ }^{2}$ As for the progressive and activist elements of international civil society, the Palestine/Israel issue has become downright emblematic. Its "in-your-face" challenge to human rights and international law, epitomized by the outrageous scale, impact, and audacity of Israel's separation wall, is raising the struggle against the occupation to the level of the anti-apartheid struggle. In other words, the international public is starting to "get it." The unequivocal ruling of the International Court of Justice that the wall being built by "Israel, the occupying power, in the occupied Palestinian territory. . . is contrary to international law," ratified by a $150-6$ vote in the UN General Assembly, lends strong legal and moral support to international efforts to end the occupation. ${ }^{3}$ So, too, do the American Presbyterian Church's calls for "the initiation of a process of phased selective divestment in multinational corporations operating in Israel" and that of the latest European Social Forum for sanctions on Israel "as long as it continues to violate international law and the human rights of the Palestinian people."

Unfortunately, however, at the very moment when the iron is hot, when naked Israeli brutality highlights just how intolerable and untenable the 
situation is, when the prospect of a new proactive Palestinian leadership raises new hopes, we, advocates of a just and viable peace, find ourselves paralyzed. We lack an agreed-upon and achievable endgame, not to mention the strategy, organization, and resources to realize it. What it is that we are advocating? A two-state solution? Does anyone really believe that is still attainable? If not, are our efforts to end the occupation strategic, or are we simply trying to reach negotiations with the strongest possible demands? And with the resumption of negotiations a possibility, how should we engage with the Palestinian leadership, and they with us?

A post-Arafat era might initiate a new, more proactive political dynamic.

Like the South African whites, Israeli Jews will not actively resist an end to the occupation but neither will they take any proactive steps to end it by electoral means.
But effective leadership of what must be an international effort to defeat Like the South African whites, they will not actively resist an end to the occupation but neither will they take any proactive steps to end it by electoral means, especially given the complete absence of alternative political leadership to Sharon on either the part of Labor or of the Zionist liberal-left led by the Yahad party of Yossi Beilin.

Israeli apartheid needs more than a new figure. It needs a new political vision in order to forge an international movement against the occupation and for Palestinian independence just as effective as the anti-apartheid movement eventually became. This is especially crucial since the Israeli Jewish public, much like the white population of apartheid South Africa, has taken an entirely passive position regarding the resolution of the conflict. While polls indicate that up to 70 percent of Israelis have little interest in maintaining the occupation, ${ }^{6}$ they have been convinced by the leaders of both Labor and Likud that there is no political solution and no "partner" for peace. Faced with what they see as an irresolvable situation, hunkering down in the hope that the wall and Sharon's brutal repression will bring relief from terrorism, they have literally taken themselves out of the political game.

With formal diplomatic efforts unlikely to lead to a just and sustainable peace, the ball is squarely in the court of the international civil society. This being the case, we urgently need to turn our attention to devising a coherent program, an effective set of priorities, and effective joint initiatives at a historical junction when Israel's occupation is at its strongest yet most vulnerable in years. This paper is intended to highlight the obstacles to effective advocacy. Where are we in our struggle for a just and sustainable peace? Where are we going? How are we going to get there? In this time of transition, these fundamental questions become more pertinent than ever.

\section{From the “Default" Approach to a Middle Range Strategy}

What political program should we be advocating? The two-state solution remains the only program supported by the Palestinian Authority (PA). Although the PA has indicated openness to certain adjustments, it continues to advance a two-state solution based on a complete end to the occupation, Israeli 
withdrawal to the 1967 lines, and resolution of the refugee issue through a "package" of restitutive measures (Israeli acceptance of the right of return, acknowledgement of its responsibility in creating the refugee issue, and practical arrangements for resolving the problem). This "default" approach seems to rest on the supposition that the occupation will eventually collapse due to its very injustice, continued Palestinian resistance, sumud ("steadfastness"), and international pressures and that a Palestinian state will somehow emerge through some almost mystical historical process to be encouraged but not really directed or led. Palestinian advocacy in such conditions has taken the form more of litanies of wrongs committed against the Palestinians than effective critiques of the political situation and proactive measures. (A notable exception is the challenge to the wall initiated and directed by Nasser al-Kidwa, the PA's representative to the UN.) The default nonstrategy is especially inadequate in that it is up against Israel's aggressively proactive initiatives, where the terms ("war on terror," "no partner for peace," "separation"), programs ("disengagement"), and downright falsehoods (Barak's "generous offer") have allowed it to frame the conflict and thereby control the discourse surrounding it.

What appears to be missing on the Palestinian side are two elements of effective advocacy: a vision, or at least an achievable endgame, and an effective strategy accompanied by effective organization. But here a strategic decision must be made. If we are genuinely advocating a two-state solution, then it can no longer be merely a default position. The PA must proactively pursue it while reaffirming to the activist community that this actually is the endgame. If, on the other hand, a viable two-state solution is adjudged to be gone and is in fact merely an opening tactical position when negotiations resume, then the Palestinian leadership, together with its civil society allies at home, in Israel, and abroad, must formulate a fallback position-actually the "real" endgame. What this would entail is what may be called a "middle range" strategy. It goes beyond the current "default" nonstrategy by fostering a vision of where we are heading, but at the same time it does not commit the Palestinians to a particular solution and therefore does not undermine the demand to end the occupation.

A first step toward developing effective middle range advocacy strategy might be to hold a wide-ranging discussion over possible scenarios, their acceptability, their likelihood of success, and the operational implications of each. Exploring a range of options better prepares the Palestinians for the day when negotiations do indeed resume and when the need for radical alternatives to the two-state solution may have to be formulated, and quickly. Such brainstorming helps ensure that any fallback position will be based on principles agreed upon by the Palestinian and international communities. At the same time, it encourages activists and advocates to look at the big picture.

\section{Where Are We Going? Red Lines AND Options}

The middle range strategy of advocacy being proposed here aims to achieve a just and sustainable resolution of the Israeli-Palestinian conflict. What, then, 
are the essential elements of such a resolution? These include the following:

- National expression for the two peoples. The conflict is between two peoples, two nations, each of which claims the collective right of self-determination. This is what gives such compelling logic to the two-state solution and what raises questions about the viability of the one-state idea.

- Viability. Whatever form a Palestinian state takes, it must be viable as well as sovereign. It must control its borders and basic resources (such as water) and possess territorial contiguity. Above all, it must be able to develop a viable economy if it is to be responsible for resettling and rehabilitating the refugees who choose to return-to say nothing for coping with its present population, more than 60 percent of which are under the age of 25 , which is traumatized, impoverished, and left with little education and few skills.

- Refugees. Needless to say, any sustainable peace is dependent upon the just resolution of the refugee issue. Israel must acknowledge the refugees' right of return; it must acknowledge its role in creating the refugee issue so that a healing process may begin; and only then will a just resolution be formulated that takes into account both the refugees right of choice and Israel's concerns. (Here I believe the confederational approach, mentioned below, holds great promise.)

- A regional dimension. Despite our almost exclusive focus on Palestine/Israel, the main issues facing both peoples of that country-refugees, security, water, economic development, democratization-are regional in scope and must be addressed accordingly.

- Israel's security. Israel's legitimate security concerns must be addressed. However, Israel's concept of security cannot be so broad and encompass so many elements of control that it leaves no breathing space for the Palestinians. One way of assuaging basic fears while not permitting "security" to be used as a pretext for continuing occupation could be the introduction of a meaningful time dimension in the peace process.

Defining the essential elements of a just and sustainable peace permits us to formulate and evaluate the range of alternative solutions. They can be reduced to four possible options, with only the last one, I would argue, being truly just and sustainable:

The first is the traditional two-state solution in which a Palestinian state emerges on all of the occupied territories (with minor adjustments). This is, as mentioned above, the current "default" position of the PA. I have argued with others (most notably the PLO's Negotiations Support Unit and Israeli historian 
Meron Benvenisti) that this option has been all but foreclosed, and I have yet to hear compelling arguments for its viability. Although the Palestinians must open any renewed negotiations with their "default" position, it will soon become evident that it is unachievable.

An "Israel plus, Palestinian minus" version of the two-state solution would permit a semisovereign, semi- to nonviable Palestinian state to arise in the areas between settlement blocs. Pursued by both Labor and Likud, the Palestinian Bantustan idea-"cantonization," to use Sharon's phrase-constitutes little more than a Middle Eastern version of apartheid. Leaders of both parties believe that with the Palestinians facing military defeat, impoverishment and emigration/transfer, political isolation and the "Iron Wall" of Israel's permanent presence, a "cooperative" Palestinian leadership can be found that would, with certain cosmetic inducements, accept this option. The Likud and Labor approaches differ only in detail: the former, loath to relinquish any of the "Land of Israel," believes it can impose a smaller ministate; the latter, concerned that the Bantustan appear "sellable," advocates a larger but still nonsovereign or nonviable ministate on up to 85 percent of the territories. The Geneva Initiative of Yossi Beilin and Yasir 'Abid Rabbuh is, in my opinion, a benign version of this option. It is presented as viable mainly because it "compensates" the Palestinians with certain territorial swaps so that they "receive" a full 22 percent of the original Palestine (the same percentage represented by the occupied territories). Even so, it leaves the Palestinians with less than a coherent territory and leaves Israel with the major settlements (including East Jerusalem), much of "Greater" Jerusalem, and the rich farmlands and water resources of the western West Bank; it also fails adequately to address the refugee issue.

A single state, either binational (although the Israeli Jewish and Palestinian populations are too mixed to achieve any territorial discreteness) or democratic, on the surface seems the most natural alternative to a two-state solution; after all, it arises out of an Israeli refusal to countenance a viable Palestinian state and recognizes that Israel itself has made Palestine/Israel into one country through its settlement enterprise. Yet as a stand-alone solution it suffers from fatal flaws, most notably total opposition by the Israeli Jewish population and by a significant sector of the international community (including the United States and most if not all of Europe) because it entails the transformation of Israel from a Jewish state into a unitary democratic one (with an almost immediate Palestinian majority even without a refugee return). From the Palestinian perspective, and even though a single binational state was the official PLO position, it has serious drawbacks as well, including the prospect of becoming a permanent underclass given the far stronger institutional, educational, and economic development of the Israeli Jewish sector. This is a genuine concern, of course, but it underestimates the vital role that the Palestinian Diaspora could play in the nation-building process, a major but neglected factor in the equation. More salient, perhaps, is the argument that with the international community backing the two-state solution, reaffirmed in UN resolutions going 
back to partition, it is counterproductive to shift to a one-state solution, especially given the unlikelihood that such an approach would win international support.

Finally, a "two-state plus" solution envisions an Israeli-Palestinian (and perhaps Jordanian) confederation (later expanding into a Middle East Union encompassing Syria, Lebanon, and other states in the region). Since this introduces a crucial regional dimension, it appears to me the only acceptable and workable endgame. It represents a win-win approach that addresses the underlying cause of the conflict yet respects the integrity of each member state. (This is not code for a "Jewish" state, but rather for the integrity of Israel as a state in its own right. Whether Israel eventually evolves into a normal democratic state belonging to all its citizens is another issue and another process that needn't concern us here.) Much like the European Union, a regional confederation rests on the balance between national sovereignty and the freedom to live and work within the entire region. It separates, as the traditional two-state proposal can no longer do, the issue of self-determination from that of economic viability.

This regional approach could take the form of a "two-stage solution." Recognizing that Israel will not return to the 1949/1967 lines and not foreseeing any territorial swaps that will translate into a viable Palestinian state, it asks that the Palestinians accept a state on something less than the entire occupied territories (perhaps on the Geneva model or the 96 percent suggested by Clinton) on condition that, within a reasonable period of time (five to ten years), the international community guarantees the emergence of a regional confederation. In such a confederation all residents have the right to live and work anywhere they choose. This breaks the Palestinians out of their Bantustan. Rather than burdening the small emergent state with responsibilities it cannot possibly fulfill, the confederational approach extends that burden across the entire region. It also addresses the core of the refugee issue, which is individual choice. Palestinians residing within the confederation would have the choice of becoming citizens of the Palestinian state, retaining citizenship in their current countries of residence, or leaving the region entirely for a new life abroad. They could choose to return "home" to what is today Israel, but they would do so as Palestinian citizens or citizens of another member state. Israel would be under no obligation to grant them citizenship, just as Israelis (former "settlers") living in Palestine would retain their Israeli citizenship. This addresses Israeli concerns about the integrity of their state while neutralizing the occupation by integrating the settlements.

Such a win-win scenario also recognizes that because the fundamental problems underlying the conflict are regional in scope-refugees, water, economic development, interreligious and interethnic conflicts, security and democratization, to name just a few-no sustainable peace is possible without addressing the region as a whole. This relates directly to the issue of the endgame. If, as I argue, the regional dimension is essential for a sustainable resolution to the 
Israel-Palestine conflict, it is not enough to assume (or hope) that the two-state solution will "inevitably" evolve into a political form desired by the Palestinians. Indeed, the very first article of the Geneva Initiative, by far the most liberal and "accommodating" proposal to the Palestinians, states that when signed the agreement ends the conflict and settles all claims and grievances. In Israel-speak this means the end of the process, period. No evolution promised, none intended. Leaving this critical element of the endgame unaddressed only guarantees an unsustainable political arrangement, an endgame (two states) in which the required end is missing.

Among the advantages of the middle range strategy is that it allows for initiating proactive campaigns focused on Israeli attempts to foreclose a just and sustainable solution, even while being based on an explicit statement of the "red line" elements that must be part of any negotiated settlement. This releases us activists from the limitations of the two-state solution while lending vision, a clear direction, yet flexibility to our advocacy efforts. Middle range campaigns contribute measurably to international advocacy by presenting a comprehensive and coherent picture of the conflict to the public, highlighting issues of prime importance, providing direction to activist groups, and helping to develop effective strategies of communication and action.

\section{How Do We Get There? Toward a Proactive Campaign of Advocacy}

Any international effort to defeat Israeli apartheid needs a clear, compelling political vision accompanied by an aggressive and well-financed strategy of advocacy. Whether a new "hot" period of diplomatic activity thrusts the postArafat Palestinian leadership into government-based initiatives and negotiations or we remain in prolonged periods of "cold" diplomatic inactivity, reinvigoration of the international movement against the occupation is crucial. Effective advocacy empowers the Palestinian leadership in the first instance, while it prevents Israel and its allies from imposing a fait accompli in the second.

An effective action plan of middle range advocacy must fundamentally reframe the conflict in order to release an alternative just peace logic. It must also provide nuts-and-bolts organization and funding.

\section{A Fundamental Reframing}

Having laid out the essential elements of a just and sustainable settlement, effective advocacy requires these elements to be placed within a coherent, compelling reframing of the conflict. Israel has succeeded in seizing the framing, one based on "security" and the need for self-defense, and on the Palestinians as terrorists and itself as the victim. In this way it controls the parameters of the discussion, the issues to be addressed, the terms to be used, and, in the end, the conclusions to be drawn. Reframing is not intended to "answer" the 
Israeli framing. Instead, its purpose is to fundamentally alter the logic and flow of the discussion.

Reframing rests on a number of key reconceptualizations:

- Israel as the strong party in the conflict. Israel is able to avoid accountability by presenting itself as the victim. Since victims have no responsibility and enjoy the sympathy extended to the underdog, this permits it to act with impunity despite the fact that its economy is three times larger than the combined economies of Egypt, Palestine, Jordan, Syria, and Lebanon; that it is the world's fourth largest nuclear power and the fifth largest arms producer; that it possesses nuclear, chemical, and biological weapons and has never signed the nonproliferation treaty or agreed to international inspection; that it is by treaty a "strategic ally" of the United States-not to mention the fact that it is the occupying power. Recasting Israel not only as the strong party in the local conflict with the Palestinians but as the regional superpower it clearly is would enable us to demand accountability. This reframing would also serve to alter the public's perception of the conflict, laying the foundations, for example, for a campaign of sanctions. Highlighting human rights violations while disabusing the public of the notion that Israel is in an existential fight for its life opens the way for demands that international law - and in particular the fourth Geneva Convention-be applied.

- The root problem is occupation, not Palestinian terrorism. Framing its policies as merely defensive responses to Palestinian terrorism while removing even the term "occupation" from the discourse represents one of Israel's great PR successes. A reframing places the occupation at the very center of the discussion.

- The occupation as a proactive policy. Israel's framing of its occupation policies in terms of security and self-defense masks the meticulous longterm planning that went into creating Israel's matrix of control-the settlements, the infrastructure of highways that incorporate the West Bank and East Jerusalem irreversibly into Israel, closures, massive land expropriations and house demolitions, the invasive wall-as-border. We must highlight the occupation's function as a proactive claim to the entire country, and expose the internal contradictions between Israel's security framing and its proactive policies. The struggle should be recast proactively as the Palestinian people's seeking freedom from oppression.

- The conflict is a political one, not a clasb of civilizations. Israel's framing depoliticizes the conflict by shifting the blame for its continuation to the Palestinians, the wider Arab world, and (implicitly) Islam. This framing, like the post-9/11 discourse to which it is tied, 
presents the conflict as a clash of civilizations, thereby eliminating the possibility of a political solution; Barak's famous claim that there is no "partner for peace" is an aspect of this. Insisting that the conflict is a political one between two peoples prevents a self-serving mystification on Israel's part, while placing the Palestinians on equal footing.

- It is the Palestinians who have made the "generous offer." The Palestinians' repeated recognition of Israel within the 1949/1967 boundaries entails relinquishing their claim to 78 percent of historic Palestine. Emphasizing this fact is crucial to offsetting the political mileage Israel has gotten from Barak's (mythical) "generous offer." Such a recasting also calls attention to the peace treaties Israel has with Egypt and Jordan; formal and semiformal ties with most of the states in the Middle East, North Africa, and the Muslim world; and, not least, the 2002 Saudi Initiative in which the Arab League offered Israel regional integration if it would relinquish its occupation.

- Respect for human rights ultimately serves all parties. Because human rights are universal and internationally agreed upon, they provide a useful basis for evaluating a situation and highlighting the sources of injustice and responsibility. And since Israel is the strong party pursuing a proactive policy of expansionism in violation of international law, human rights provides the instrument by which Israel can be held accountable. A rights-based approach is also valuable in that it addresses the issue of terrorism, a central element in Israel's framing. By asserting the inadmissibility of attacks on civilians, it highlights not only nonstate terrorism "from below" but also the far more deadly state terrorism "from above." Indeed, in terms of the security needs of all the parties to the conflict, a reframing of the solution that insists on conformity to the fourth Geneva Convention, UN resolutions, international law, and human rights conventions provides the most effective "road map" to a just-and ultimately win-win-resolution.

- An emblematic conflict with global impact. In terms of connecting to the wider public, one of the first questions we must address is: Why should I care at all about this conflict? My aim here is not to dictate a script, but I would only suggest a framing that brings the international public into the equation. Presenting the Israeli-Palestinian conflict as emblematic serves this purpose. Its significance as an arena in the struggle between American empire and the incipient forces promoting human rights and international law should be highlighted. For American audiences in particular, this question should be supplemented by considerations of the conflict's negative impact on the global standing of the United States. How does the deep American involvement in sustaining the occupation impact, for example, the "war on terror" that so preoccupies the American public? 
It has to be said that advocates for a just peace in Palestine/Israel have a much harder "sell" than did the anti-apartheid movement. Not only do they have to contend with images of the Arabs (and especially the Palestinians) as terrorists, greatly compounded by $9 / 11$, but they face a moral framing that makes compelling sense: Jews as victims fighting once again for their existence in a little state arising from the ashes of the Holocaust. Zionism - and by extension Israeli policies that are carefully couched in terms of religion, rights, security, and history's debt to the Jews-enjoys a legitimacy that apartheid completely lacked. Thus, while opponents of the apartheid regime were seen as supporting the forces of liberation and the struggle against racism, critics of Israeli policies are accused of anti-Semitism. All this obliges us to reframe the conflict in ways that will help overcome a powerful reluctance to pressure Israel, a situation that, on the surface at least, the African National Congress did not have to confront.

\section{Organization}

Finally, a proactive middle range strategy of advocacy requires much better organization and funding. This means, at a minimum, better coordination, the establishment of forums for ongoing strategizing, and the development of focused and strategic campaigns.

A middle range approach fostering focused, proactive, coordinated international campaigns rivaling Israel's sophisticated PR efforts would rejuvenate the network of NGOs, faith-based groups, journalists, academics, and government officials that stand by the Palestinian cause. As in the "default" approach, the demand to end the occupation would lie at the center of such campaigns. While alternative scenarios would be raised, discussed, and evaluated in public forums, no specific postoccupation plan would be advanced. We might hope that the PA would play as directed a role as the Israeli government, with its expansive network of lobbies, diplomats, religious and other groups, NGOs, the media-indeed, entire governments. (An "Israelization" of American foreign policy has been commented upon frequently, most recently by General Zinni in relation to Iraq.) That being unlikely, we could at least demand that the PA appoint an international civil society coordinator. This would ensure that campaigns and actions would conform to the PA agenda, while giving latitude to activist groups. Similarly, there is a pressing need for better Palestinian representation in the world's capitals and other influential places; effective access to decision- and opinion-makers would make our collective work all the more effective.

Important steps have been made to better coordinate the working relations among the hundreds of civil society groups directly or indirectly involved in the Palestinian issue. Numerous conferences and meetings have been held on key topics, and the World, European, and Mediterranean Social Forums are increasingly used as venues for meeting, coordinating, and strategizing. It seems imperative, however, to reestablish the International Coordinating Committee on Palestine, which until the mid-1990s worked out of Geneva. The International Coordinating Network on Palestine set up by the UN Division of Palestinian 
Rights aspires to provide such a framework but has not yet crystallized as an effective body. Other global frameworks should also be explored and developed.

On a regional level, the regional coordinating committees that once existed should be reinvigorated or reestablished. A European Coordinating Committee on Palestine exists in Belgium and is headed by Senator Pierre Galand but needs more vigorous leadership. North America, Latin America, Africa, and Asia all lack coordinating committees. (With 120 member organizations, the U.S. Campaign Against the Occupation could fill the function of a U.S. Coordinating Committee on Palestine if it expanded its mandate from an exclusive focus on American government support for the occupation to include support for the advocacy efforts of Palestinian, Israeli, and European organizations.) Without such coordinating frameworks, the myriad individuals, groups, and organizations involved in the Palestine issue will find it difficult to transform a global but unwieldy network of activists into a mobilizable and focused movement reminiscent of the one against apartheid. Palestinian and Israeli groups need to find ways in which to interface with their international partners.

Next, we must create effective forums for collective strategizing. The weakness of the PA in providing leadership for the civil society requires first and foremost a forum for intra-Palestinian discussion involving Palestinians "inside," the refugee communities, and the Palestinian Diaspora. Here the various voices would be heard and lines of strategic campaigning, if not a definitive endgame, could be thrashed out. Perhaps spokespeople and representatives better able to articulate the Palestinian case in the halls of power and to guide non-Palestinian activists and advocates would emerge from this pool. At some point the discussion should open up to include Israeli (and Diaspora Jewish) partners in the struggle for a just peace. With all due respect to hesitations to "normalize" relations with Israelis, a liberation movement unable to differentiate between genuine partners in the opposing camp and unreliable interlocutors severely limits its range of effective action.

In this, the Palestinian Diaspora could play a major role. The refugees in the camps-poor, isolated, fragmentized, virtually invisible, and having the largest stake in the outcome-have been largely excluded from active participation in the national dialogue and in the various diplomatic initiatives. The far-flung Palestinian Diaspora, traditionally an educated and affluent community, well connected and far more plugged into the international scene than the PA, has the ability to press and even challenge the Palestinian leadership in a way the Palestinian NGOs "inside" cannot. So far, this community has been largely passive aside from occasional solidarity meetings and a few outspoken intellectuals. This is understandable given the reluctance of immigrants to speak out, especially Muslim Palestinians in the hostile post-9/11 atmosphere. This only heightens the role that international activists must play, unless a core group of Palestinian intellectuals and activists, if not the PA itself, takes a more proactive stance (recognizing the important Diaspora voices that $d o$ exist).

Once a structure of advocacy is in place, a well-coordinated set of campaigns focused on the most relevant issues and target populations may be launched 
with the ultimate aim of becoming a global movement. Here, the occupation itself must be the focus of the resistance and advocacy efforts. Activist groups in Israel and abroad, lacking an overarching campaign and strategy, pursue a myriad of very important issues but often are not ones that will actually bring an end to the occupation. The campaign against the wall, resisting home demolitions, harvesting olives, boycotting Caterpillar, lobbying to suspend the EU-Israel Association Agreements, monitoring checkpoints, accompanying Palestinian children to school-these and similar activities highlight the sins of the occupation but collectively do not constitute an effective and coherent campaign to resolve the conflict. On the contrary, they often come dangerously close to what Paulo Freire refers to as "dumb activism."

What is called for are strategic "metacampaigns" that highlight the occupation and the attendant human rights violations, Israeli accountability, and the international community's responsibility toward the Palestinians. Such metacampaigns might include a campaign to apply the fourth Geneva Convention to the occupied territories; a campaign against apartheid; a campaign to freeze Israeli construction in the occupied territories; a campaign to stop Israel's use of U.S. weapons against Palestinian civilians and - not least-a campaign of divestment/sanctions. None of these metacampaigns need to replace important microcampaigns and actions against particular manifestations of the occupation such as house demolitions, settlement expansion, or the building of the wall.

\section{Providing Support in Times of "Hot" or "Cold" Diplomacy}

One of the greatest handicaps we face is trying to formulate coherent and effective strategies in a situation marked by dramatic shifts between "hot" and "cold" periods of diplomatic activity. This paper suggests a strategy of civil society advocacy that assumes long interstices in the diplomatic process. Israel has long endeavored to delay a final settlement indefinitely-Sharon is on record as preferring a "longterm interim agreement." That said, Israel after Arafat also has an interest in nailing down the Palestinian Bantustan if a quisling Palestinian "leader" - a "moderate and pragmatic leader" in Israeli code-can be found who will sign off on it. It is possible, then, that a "hot" period of diplomatic activity may be on the horizon. Should diplomatic activity in fact heat up, civil society will have a vital role to play in advocating for a just peace and strengthening the bargaining position of the Palestinian leadership. If we have done our work well, the logic and parameters of the Palestinian negotiating position will be known and understood by the international public. On the other hand, any serious pressure on Israel to agree to a just solution containing the essential elements outlined above will result in the long "cold spells" we have seen in the past ("formaldehyde" in the words of Dov Weisglass, the head of the Prime Minister's Office). In either case, hot or cold, grassroots activismPalestinian, Israeli, and international alike-will be needed in a political process that pits a powerful state against an occupied people possessing only a limited governmental authority with no sovereign territory. 
Energy and commitment are not enough, however. Effective activism requires leadership and direction, first from the PA, then from Palestinian civil society, and finally from the Israeli peace camp-none of which we have received. Our collective ability to exploit the present historical moment calls for urgent consultation, intra-Palestinian as well as with Israeli and international partners, leading to effective action. But in order to maintain public support, especially given Israel's sophisticated PR, the Palestinian leadership must communicate and engage with us. I hope that in the post-Arafat era the Palestinian leadership appreciates this.

I hope that this paper will generate constructive discussion and action. A middle range approach that generates a proactive strategy of advocacy has the potential to become a global movement akin to the anti-apartheid struggle. Under Palestinian guidance, but in coordination with the Israeli peace movement and international activists, such a movement must provide direction, effective forums for strategizing, reframing and the formulation of focused and strategic campaigns. It must impart a vision, principles, red lines, and alternative scenarios. These are critical steps at this historical moment. As the old slogan has it: "When the people lead, the leaders follow."

\section{NoTES}

1. ICAHD figures are compiled from reports and figures released by Amnesty International, B'Tselem, the Israeli Civil Administration, the Jerusalem municipality, and UNRWA. More information is available online at www.icahd.org.

2. Andrew Beatty, "Poll Controvery as Israel and U.S. Labeled Biggest Threats to World Peace," Euobservercom, 30 October 2003, online at www.euobserver. com.

3. For excerpts from the International Court of Justice's advisory opinion, see
Document A3 in JPS 34, no. 1 (Autumn 2004), pp. 152-54.

4. Presbyterian Church (U.S.A.), Resolution on Israel and Palestine (2004), 216th General Assembly (Richmond, 2004), online at www.pcusa.org.

5. European Social Forum, "The Call of the Assembly of Social Movements," London, 17 October 2004, online at www.fse-esf.org.

6. Ma'ariv International, "Poll: $76 \%$ of Israelis, Palestinians Support Two-State Solution," 26 May 2004. 